\title{
PEDAGOGU KVALIFIKACIJOS TOBULINIMO EFEKTYVUMAS ANDRAGOGO ORGANIZATORIAUS VEIKLOS ASPEKTU
}

\author{
Nomeda Skliuderienè, Gitana Tolutienė \\ Klaipedos universitetas
}

\begin{abstract}
Anotacija
Mokslinès literatūros, LR teisès aktų ir atliktų tyrimų Lietuvoje analizė atskleidè, kad pedagogu kvalifikacijos tobulinimas, susijęs su suaugusiujų švietimu ir mokymo / mokymosi organizavimu, yra aktualus kaip mokytojų ne tik pedagoginès, bet ir andragoginès veiklos tobulinimo bei naujų kompetencijų igijimo šaltinis. Tačiau šis procesas yra sudetingas, susidedantis iš profesinès veiklos i(si)vertinimo, planavimo, tobulinimo(si), praktinio pritaikymo, refleksijos, o kokybės užtikrinimo aspektu tai besikartojančių kokybės tobulinimo veiksmų ciklas. Suvokiant, kad šio proceso sèkmingam ir kokybiškam iggyvendinimui andragogo organizatoriaus profesionalumas yra viena svarbiausiu sąlygų, straipsnyje keliamas probleminis klausimas, koks yra andragogo organizatoriaus profesionalumo vaidmuo, siekiant pedagogų kvalifikacijos tobulinimo efektyvumo? Atliktas tyrimas patvirtino andragogo organizatoriaus profesionalumo reikšmę šio proceso efektyvumui. Nustatyta, jei pedagogų kvalifikacijos tobulinimo procesą andragogas organizatorius realizuos profesionaliai, pradedant pedagogų mokymosi poreikių tyrimu ir baigiant igytų kompetencijų praktiniu pritaikymu, bus pasiektas pagrindinis pedagogų kvalifikacijos tobulinimo tikslas - jų profesinès veiklos bei naujų kompetencijų igijimo kokybė. Praktiniu požiūriu šiame straipsnyje pateikti empiriniai duomenys gali būti reikšmingi: 1) siekiant atskleisti Klaipėdos rajono švietimo centro, teikiančio pedagogų kvalifikacijos tobulinimo paslaugas, veiklos efektyvumą; 2) gerinant ir užtikrinant šio proceso kokybę; 3) siekiant andragogo organizatoriaus profesionalizacijos (vidaus profesionalizacijos - profesinių kompetencijų tobulinimo, gilinantis ị tyrimo duomenų analizę; išorès profesionalizacijos - andragogo organizatoriaus profesionalumo, siekiant pedagogų kvalifikacijos tobulinimo efektyvumo, pagrindimo).

PAGRINDINIAI ŽODŽIAI: andragogas organizatorius, profesionalumas, pedagogų kvalifikacijos tobulinimas, efektyvumas.
\end{abstract}

\begin{abstract}
Scientific literature, LR legal acts and analysis of research conducted in Lithuania shows that the process of teachers' qualification development is related to adult education and organization of teaching / learning, is relevant as a source of improvement of teachers' pedagogical as well as andragogical activity and acquisition of new competences. But this process is complicated and consists of professional activity's self-assessment / assessment, planning, self-improvement / improvement, practical application, reflection and as an aspect of quality assurance it is a repeated cycle of actions to improve quality. Knowing that andragogue organiser's professionalism is one of the most important conditions for this process to be successfully and qualitatively implemented, the issue raised in this article is: what is the role of andragogue organiser's professionalism in striving for effectiveness of teachers' qualification development? The conducted quantitative research confirmed the importance of andragogue organiser's professionalism for the effectiveness of this process. It is found that the main objective of teachers' qualification development, that is, the quality of their professional activities and the acquisition of new competences will be achieved if the andragogue organiser will professionally implement the teachers' qualification development process beginning with analysis of learning needs and ending with practical application of acquired competences. In the practical appro-
\end{abstract}




\section{Nomeda Skliuderienè, Gitana Tolutienè}

ach empirical data presented in this article can be significant in: 1) seeking to reveal the effectiveness of activity of Klaipeda District Education Centre that provides teachers' qualification development services; 2) improving and ensuring the quality of this process; 3) achieving andragogue organiser's professionalism (internal professionalism - improvement of professional competences by examining the analysis of research results, external professionalism - justification of andragogue organiser's role of professionalism in the effectiveness of teachers' qualification development).

KEY WORDS: coordinating andragogue, professionalism, educators' qualification training, efficiency.

DOI: http://dx.doi.org/10.15181/tbb.v82i1.1963

\section{Ivadas}

Šiuolaikinè žinių visuomenè ir švietimo sistemos kaitos procesai kelia vis naujus pedagogų kvalifikacijos reikalavimus ir skatina pedagogus tobulèti. LR Švietimo įstatymo (2011) 2 straipsnio 20 dalis nustato, kad pedagogo kvalifikacija - LR teisès aktų nustatyta tvarka pripažistama asmens turimų kompetencijų arba profesinès patirties ir turimų kompetencijų, kurios būtinos ugdant mokinius, visuma. Kadangi įstatymų reglamentuojamam pedagogo darbui atlikti reikia tam tikros kvalifikacijos arba kompetencijų, iš šios 2 straipsnio nuostatos išplaukia, kad, siekiant aukštesnès švietimo ir mokymo / mokymosi kokybės, pedagogų kvalifikacijos tobulinimas yra viena pirmujjų būtinų šio siekinio sąlygų. Tačiau kyla klausimas, pats pedagogas gali susidoroti su šiais procesais tobulindamas savo profesinę veiklą ar jam reikia kompetentingos pagalbos iš šalies, t. y. profesionalaus andragogo organizatoriaus?

Išanalizavus pedagogo ir andragogo sąveiką bei andragogo profesinès veiklos sritis, funkcijas, kompetencijas, vaidmenis, galima teigti, kad būtent andragogas organizatorius ir padeda pedagogui ịsivertinti savo veiklą, nustatyti profesinès veiklos sėkmes ir tobulintinas puses, numatyti kvalifikacijos tobulinimo kryptị ir kt. Lietuvoje šias funkcijas atlieka mokyklų direktorių pavaduotojai ugdymui, švietimo skyrių specialistai, stebintys ir vertinantys pedagogų profesinę veiklą, pedagogų švietimo centrų specialistai, glaudžiai bendradarbiaujantys su ugdymo įstaigomis. Pedagogų kvalifikacijos tobulinimo (toliau - PKT) kokybės užtikrinimo aspektu pagrindinị vaidmenį atlieka andragogas organizatorius, kuris PKT procese veikia edukacinès, vadybinès, tiriamosios profesinès veiklos srityse.

LR Švietimo įstatymas (2011), Valstybès švietimo strategijos 2013-2022 m. nuostatos (2013), PKT koncepcija (2012), Reikalavimų mokytojų kvalifikacijai aprašas (2014) ir kiti PKT reglamentuojantys dokumentai apibrèžia pedagogui keliamus reikalavimus bei PKT galimybes. Tačiau, suvokiant PKT sąsajas su suaugusiųų švietimu ir mokymo / mokymosi organizavimu, PKT pripažįstant kaip 
mokytojo ne tik pedagoginès, bet ir andragoginès veiklos tobulinimo bei nauju kompetencijų igijimo šaltini, tenka pastebèti, kad PKT dažnai būdingas fragmentiškumas, stinga PKT poreikių tyrimų, planavimo, ryšio su švietimo ir mokymo / mokymosi procesu bei praktinio pritaikomumo, tai ir pagrindžia šio straipsnio aktualumą. Kita vertus, pastaraisiais metais kyla nemažai prieštaravimų valstybès švietimo institucijose dẻl PKT paslaugų teikẻjams keliamų reikalavimų bei jų teikiamų paslaugų kokybės užtikrinimo.

Priešingai nei PKT procese dalyvaujančių pedagogų, andragogų profesinę veiklą reglamentuojančių dokumentų skaičius yra mažas: Andragogo profesinės veiklos aprašas (2013), LR neformaliojo suaugusiujų švietimo ir tęstinio mokymosi ịstatymas (2014), Mokymosi visą gyvenimą užtikrinimo strategija (2008), Valstybès švietimo strategijos 2013-2022 m. nuostatos (2013) ir kt. Vis labiau pripažistant andragogo profesionalo svarbą rengiami ịvairių dokumentų projektai. Daugelis mokslininkų (Adomaitienè ir kt., 2016; Jatkauskienè, 2013; Andriekienè, 2011; Zuzevičiūte ir kt., 2008; Juozaitis, 2008; Andriekienè ir kt., 2006; 2009; Knowles ir kt., 2007; Teresevičienè ir kt., 2006 ir kt.), analizavusiu andragogo profesinės veiklos sritis, funkcijas, kompetencijas, realiai vykdomus vaidmenis, nustate, kad jie yra ịvairūs. Šiandien, kalbant apie PKT, akcentuojamas ne tiek mokymas, dèstymas - lektoriaus vaidmuo, kiek andragogikos ir andragoginès veiklos technologijos, parama / pagalba suaugusiam besimokančiajam, vadybos, refleksijos ir kitos veiklos sritys bei andragogų analitikų (tyrèjų), andragogų organizatorių, konsultantų, pagalbininkų, vadybininkų, mentorių atliekami vaidmenys.

Taigi, stebint švietimo politikos tendencijas ir vis analizuojamas PKT problemas, akivaizdu, kad andragogo organizatoriaus vaidmuo PKT srityje bei jo profesionalumo svarba vis dar nepakankamai pripažinta. Čia būtinos tiek tiriamoji, tiek vadybine, tiek ir kitos bendrosios bei profesinès kompetencijos. „Fragmentinis“ PKT organizavimas pripažistamas kaip probleminis, teigiamai neveikiantis pedagogų profesinès veiklos ir naujų kompetencijų igijimo kokybės. Nors andragogo profesiniai vaidmenys, veiklos sritys, funkcijos ir joms atlikti būtinos kompetencijos aprašytos Lietuvos ir užsienio šalių mokslininkų, o apie Lietuvos PKT nuolat diskutuojama, šiai nuolat analizuojamai sričiai aktualus tyrimo klausimas, koks yra andragogo organizatoriaus profesionalumo vaidmuo, siekiant PKT efektyvumo?

Tyrimo objektas: andragogo organizatoriaus vaidmuo, siekiant PKT efektyvumo Klaipedos rajone.

Tyrimo tikslas: atskleisti ir pagristi andragogo organizatoriaus profesionalumo svarbą, siekiant PKT efektyvumo.

Tyrimo metodai: atlikus mokslinès literatūros ir dokumentų analizę, vykdyta Klaipėdos rajono X ugdymo ịstaigų pedagogų apklausa, siekiant ištirti jų požiūrị ị andragogų, organizuojančių PKT procesą, veiklą, funkcijas ir kompetencijas. 


\section{Pedagogų kvalifikacijos tobulinimo efektyvumo andragogo organizatoriaus veiklos aspektu tyrimo pristatymas ir pagrindinių tyrimo rezultatų analizè}

Tyrimo apibūdinimas. Siekiant išsiaiškinti pedagogų požiūrị ị PKT efektyvumą andragogo organizatoriaus veiklos aspektu, parengtas tyrimo instrumentas, kurio klausimus sudare trys struktūriniai blokai (1 lentelè).

1 lentelè. Anketos klausimų struktūriniai blokai

\begin{tabular}{|c|c|c|c|}
\hline $\begin{array}{l}\text { Klausimų } \\
\text { blokas }\end{array}$ & \begin{tabular}{|l}
1 blokas \\
$1-5$ klausimai \\
\end{tabular} & $\begin{array}{l}2 \text { blokas } \\
\text { 6-13 klausimai }\end{array}$ & \begin{tabular}{|l|}
3 blokas \\
$14-17$ klausimai
\end{tabular} \\
\hline & Demografiniai & $\begin{array}{l}\text { PKT efektyvumas andragogo } \\
\text { organizatoriaus veiklos } \\
\text { aspektu }\end{array}$ & $\begin{array}{l}\text { Pedagogų } \\
\text { požiūris ị PKT } \\
\text { organizavimą } \\
\text { Klaipėdos rajone }\end{array}$ \\
\hline $\begin{array}{l}\text { Klausimų } \\
\text { blokų } \\
\text { turinys }\end{array}$ & $\begin{array}{l}\text { Respondentų } \\
\text { lytis, amžius, } \\
\text { pedagoginio darbo } \\
\text { stažas, kvalifikacinè } \\
\text { kategorija, } \\
\text { pedagoginès veiklos } \\
\text { sritis }\end{array}$ & $\begin{array}{l}\text { Respondentų požiūris ị } \\
\text { PKT sampratą, formas, } \\
\text { pasirinkimo kriterijus, } \\
\text { motyvacijos šaltinius, } \\
\text { andragogo organizatoriaus } \\
\text { veiklą (gebėjimus, funkcijas, } \\
\text { sritis, reikšmę) }\end{array}$ & $\begin{array}{l}\text { Respondentų } \\
\text { požiūris ị } \\
\text { andragogo } \\
\text { organizatoriaus } \\
\text { veiklos kokybę } \\
\text { Klaipėdos rajone, } \\
\text { PKT kokybės } \\
\text { užtikrinimo būdus }\end{array}$ \\
\hline
\end{tabular}

Apklausoje dalyvavo 224 Klaipėdos rajono X ugdymo ịstaigų pedagogai (visų rajone esančių bendrojo [pradinio, pagrindinio ir vidurinio] ugdymo mokyklų mokytojai, ikimokyklinio ir priešmokyklinio ugdymo pedagogai, pagalbos mokiniui specialistai), tobulinantys kvalifikaciją Klaipèdos rajono švietimo centre ir besinaudojantys andragogų organizatorių, dirbančių šioje institucijoje, paslaugomis bei kitaip susiduriantys su minètų andragogų vykdoma veikla PKT ir metodinès veiklos organizavimo srityse.

Siekiant parinkti reprezentatyvią tyrimo imtị, kuri atskleistų generalinę visumą, tyrimui pasirinkta paprastoji atsitiktinè imtis. Skaičiuojant imtį, remtasi Klaipėdos rajono savivaldybès 2016-2017 mokslo metų pedagoginių darbuotojų statistiniais duomenimis (Švietimo valdymo informacinè sistema, 2016). Nurodytais mokslo metais Klaipèdos rajone dirbo 557 pedagoginiai darbuotojai, ịskaitant vadovus ir jų pavaduotojus ugdymui. Vykdant apklausą išdalinta 250 anketų, surinkta - 232, duomenims apdoroti tinkamos - 224, t. y. 40 proc. Klaipėdos rajono pedagoginių darbuotojų nuomonè apie tiriamą problemą.

Surinktų duomenų statistinis apdorojimas atliktas IBM SPSS Statistics 21 bei MS Excel. Aprašomosios statistikos metodai taikyti pradinei duomenų analizei (sudarytos dažnių ir porinių dažnių lentelès, rezultatai pavaizduoti grafiškai, apskai- 
čiuoti rangų vidurkiai). Dviejų kokybinių požymių nepriklausomumui nustatyti taikytas Pirsono chi kvadrato $\left(\chi^{2}\right)$ kriterijus. Statistiniam reikšmingumui nustatyti pasirinktas 0,05 reikšmingumo lygmuo.

Respondentų demografinès charakteristikos. Pristatant respondentus, siekiant pagrịsti andragogo paslaugų poreikị minètų profesinių grupių atstovams, remiantis andragogų organizatorių patirtimi, galima teigti, kad ne visi pedagogai tobulina kvalifikaciją ịsivertinę savo veiklos kokybę ir aptarę stipriąsias bei tobulintinas veiklos sritis metinio pokalbio su savo įstaigos vadovu metu. Todèl dažnai andragogas organizatorius turi gebèti suteikti pedagogui pagalbą išgrynindamas, kokių kompetencijų jam stinga. Siekiant suteikti kvalifikuotą pagalbą andragogui organizatoriui būtina išmanyti pedagogų, dirbančių ikimokyklinio, priešmokyklinio, pradinio, pagrindinio ir vidurinio ugdymo įstaigose (įskaitant progimnazijas ir gimnazijas), veiklą.

Apibendrinta apklausos analizè atskleidè, kad absoliučią tyrimo respondentų daugumą sudarè moterys, jų - net 91 proc. Didžiąją dalị apklaustujų sudare 5160 m. (35 proc.) ir 41-50 m. (34 proc.) amžiaus grupès (1 pav.).

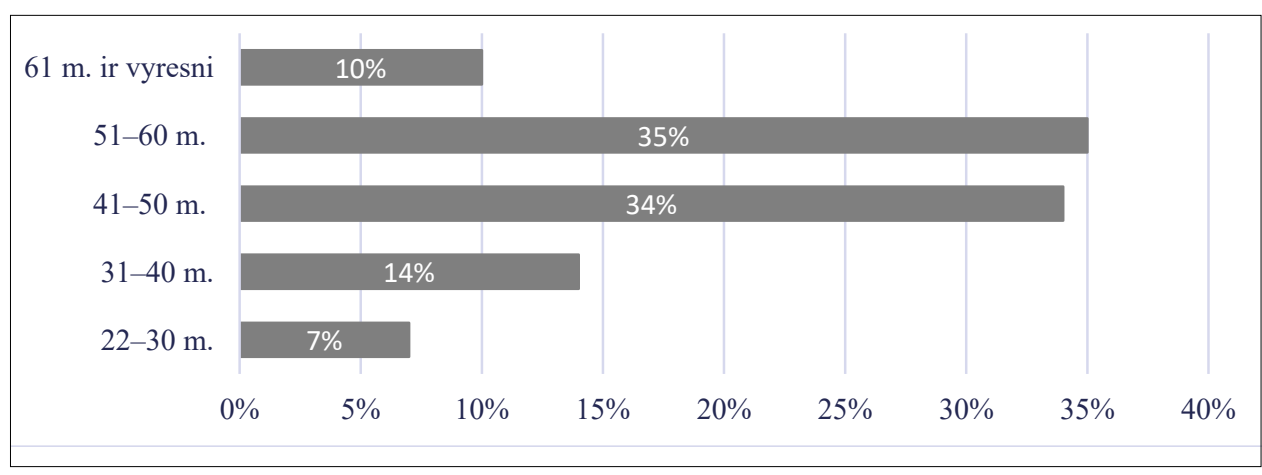

1 pav. Respondentų pasiskirstymas pagal amžių

Tarp respondentų dominuoja didesnị darbo stažą turintys pedagogai: 11-20 m. 22 proc., $21-30 \mathrm{~m}$. -33 proc. ir $31 \mathrm{~m}$. ir vyresni - 28 proc. ( 2 pav.). Todèl galima daryti prielaidą, kad tyrime dalyvavę pedagogai yra pakankamai gerai susipažinę su PKT proceso ypatumais, tobulindami kompetencijas ir igydami naujų vadovaujasi PKT sampratos principais (PKT koncepcija, 2012), gali objektyviai ịvertinti PKT efektyvumo ir andragogo organizatoriaus veiklos santykį. Pagal kvalifikacinę kategoriją respondentai pasiskirste netolygiai: beveik puse - vyresnieji mokytojai (46 proc.), kiek mažiau - mokytojų metodininkų (33 proc.) ir mokytojų (20 proc.), tuo tarpu mokytojų ekspertų - tik vienas. 
Nomeda Skliuderienè, Gitana Tolutienè

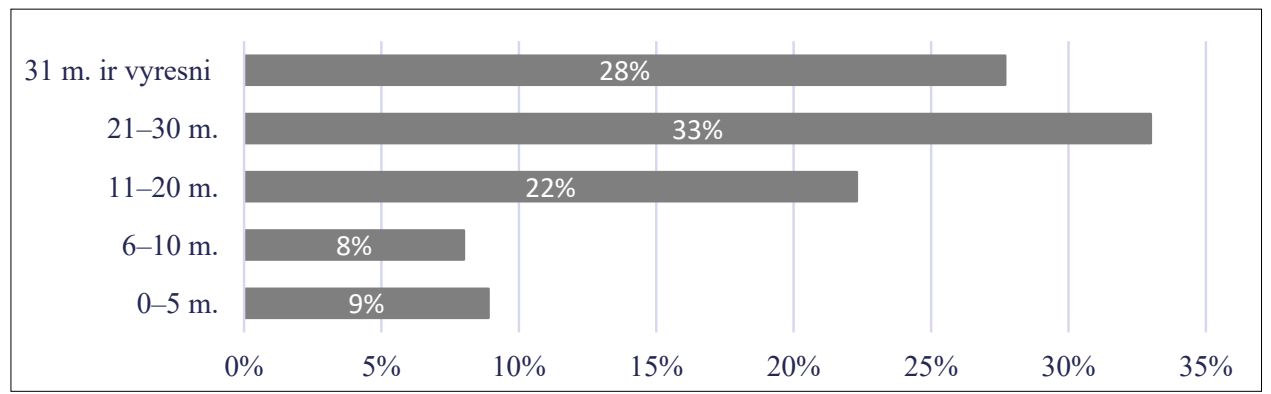

2 pav. Respondentų pasiskirstymas pagal darbo stažą

Kadangi ìvairių dalykinių grupių PKT skiriasi tiek mokymo formomis, tiek renginių gausa ar vyraujančiomis problemomis, siekiant objektyvumo, stengtasi apklausti visų pedagoginės veiklos sričių metodinių būrelių atstovus (3 pav.).

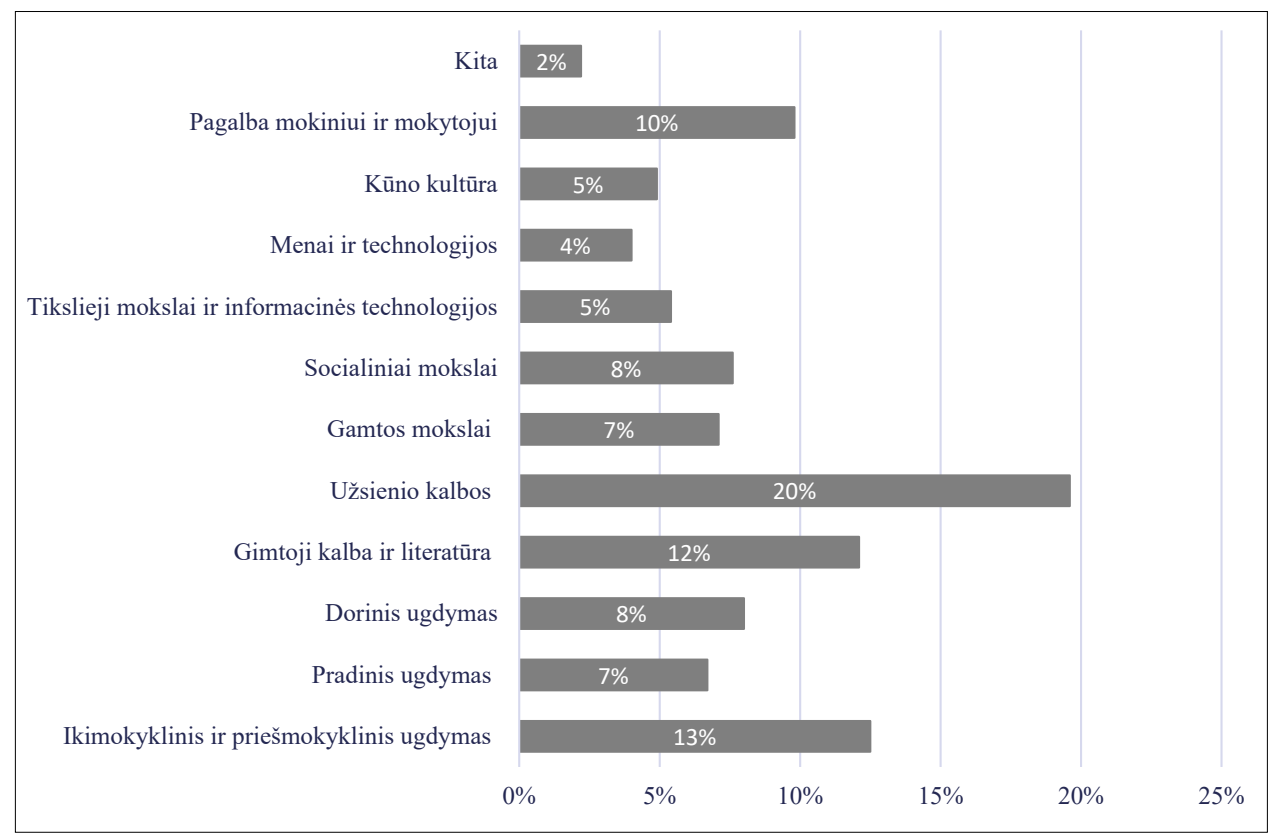

3 pav. Respondentų pasiskirstymas pagal pedagoginès veiklos sritis

Pedagogų požiūris ị kvalifikacijos tobulinimo efektyvumą andragogo organizatoriaus veiklos aspektu. Kadangi PKT, nesusietas su turima profesine patirtimi ir žiniomis, gali būti fragmentiškas ir praktikoje nepritaikomas, pedagogui svarbu 
suvokti jo prasmę ir tikslus. Remiantis empiriniais duomenimis, daugiau nei pusé (59 proc.) apklaustujų nurodè, kad efektyvus PKT - tai galimybè ịsivertinti profesinę veiklą, planuoti profesinị tobulẻjimą, susipažinti su nauja medžiaga, kūrybiškai išbandyti naujus metodus ir ịrangą (4 pav.). Kaip teigiama PKT koncepcijoje (2012), kad tokia galimybè atsirastų, kvalifikacijos tobulinimas visų pirma turi būti suvokiamas ir ịgyvendinamas kaip organizacinių, finansinių ir pedagogų bendradarbiavimą skatinančiu priemonių visuma. Beveik pusè apklaustujų (46 proc.) efektyviam PKT priskyre naujų profesinių kompetencijų igijimą. Galima daryti prielaidą, kad dauguma tyrime dalyvavusių pedagogų PKT suvokia kaip sudètingą procesą, apimanti profesinès veiklos ịsivertinimą, ne tik pedagoginès, bet ir andragoginès veiklos gerinimą, sistemingą planavimą, naujų žinių, kompetencijų igijimą ir jų praktinio pritaikymo svarbą, jie kvalifikaciją tobulina atsakingai.

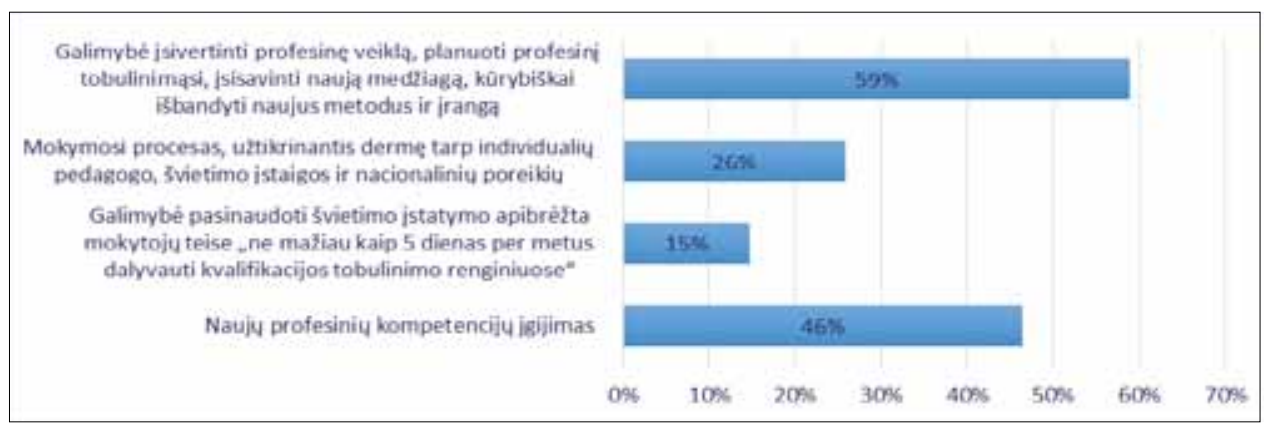

4 pav. Respondentų nuomoniu pasiskirstymas apibūdinant efektyvų PKT

Kaip parodè Lietuvos PKT sistemos analizė (2011), dažnai PKT nepasižymi aiškia orientacija ị rezultatą tiek klasès, tiek mokyklos lygmeniu. Todèl respondentų prašyta nurodyti, kokia, jų nuomone, yra efektyviausia kvalifikacijos tobulinimo forma. Daugelis nurodė praktinę mokymų naudą, kaip vieną iš prioritetų: 56 proc. pirmenybę teikia mokytojų praktikų gerosios patirties sklaidai, 51 proc. - metodiniams užsièmimams su kolegomis praktikais, patiems išbandant įvairius metodus ir medžiagą. Be to, anot apklaustujų, svarbus lektorių vaidmuo: 54 proc. nurodė seminarus, paskaitas, kuriuos veda kvalifikuoti lektoriai (5 pav.). Galima teigti, kad gauti rezultatai pagrindžia PKT koncepcijos principą, teigiantị, kad pedagogas turi perimti geriausias ugdymo praktikas, kurios daugeliu atvejų tinkamai suvokiamos autentiškoje pedagoginès veiklos aplinkoje, todèl čia turi būti sutelkta didelè pedagogams skirtų kvalifikacijos tobulinimo veiklų dalis. 


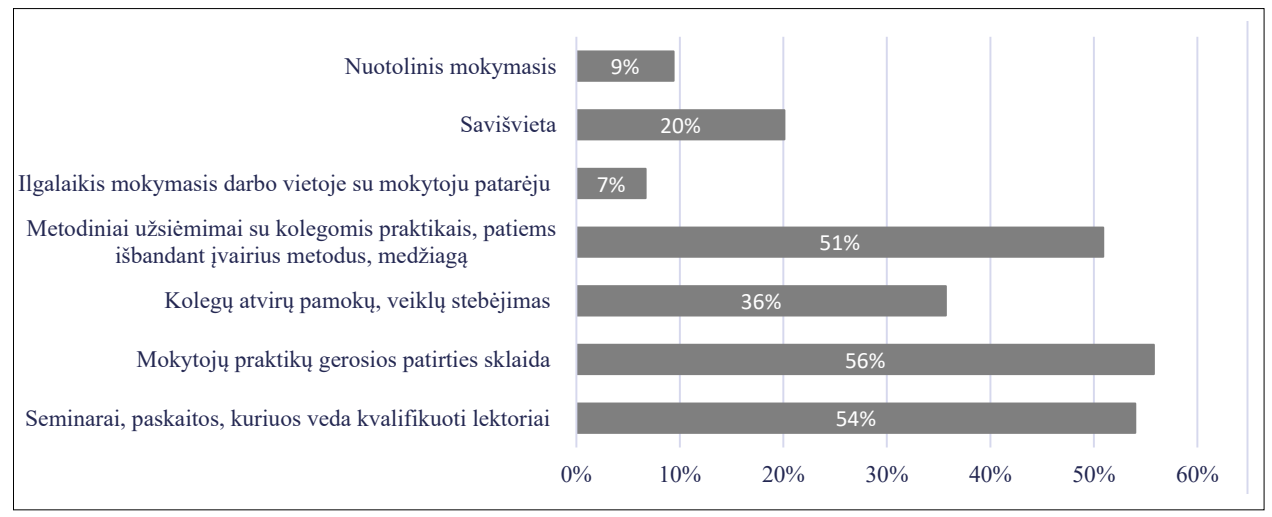

5 pav. Respondentų nuomonių pasiskirstymas apibūdinant efektyviausią PKT formą

Analizuojant PKT paslaugų kokybės ir andragogo profesinės veiklos sąsajas, respondentų teirautasi, kokias funkcijas realizuodamas andragogas organizatorius gali užtikrinti pedagogų mokymosi paslaugų kokybę. 40 proc. respondentų, kalbėdami apie PKT kokybės užtikrininimą, nurodè mokymų programos ir praktinio pritaikomumo ryšio svarbą. 36 proc. pažymèjo, kad andragogas organizatorius, siekdamas teikiamų paslaugų kokybès, turètų tirti ir atliepti pedagogų individualius mokymosi poreikius. 35 proc. mano, kad svarbu parengti efektyvias mokymo programos realizavimo strategijas. Kiek mažiau pedagogu pažymèjo palankios mokymosi aplinkos kūrimą (26 proc.) ir tinkamų mokymosi priemonių parinkimą (21 proc.). Tai rodo, kad andragogas organizatorius mokymosi paslaugu pedagogams kokybę efektyviausiai užtikrina veikdamas visose profesinès veiklos srityse: edukacinèje, vadybinèje, tiriamojoje.

Andragogui, organizuojančiam PKT ir siekiančiam atliepti pedagogų poreikius, naudinga žinoti, kokiais kriterijais vadovaujasi pedagogai ir pagalbos mokiniui specialistai, rinkdamiesi kvalifikacijos tobulinimo renginius. Dauguma (51 proc.) respondentų nurodè, kad rinkdamiesi kvalifikacijos tobulinimo renginius vadovaujasi subsidiarumo principu, t. y. savo asmeninius mokymosi, tobulèjimo poreikius stengiasi derinti su ugdymo įstaigos tikslais.

Beveik pusė apklaustujų (46 proc.) mano, kad andragogo, teikiančio PKT paslaugas, funkcijas gali atlikti andragogas, turintis teorinių suaugusiujų švietimo ir mokymo / mokymosi žinių bei praktinès administracinès, vadybinès, analitinès patirties. 37 proc. pedagogų teigia, kad šias funkcijas gali atlikti asmuo, turintis andragoginėms funkcijoms realizuoti būtinų kompetencijų. Panaši dalis apklaustujjų (34 proc.) nurodè, kad šias funkcijas gali atlikti andragogas, ịgijęs valstybès nustatytą išsilavinimą ir andragogo kvalifikaciją, kuri patvirtina galimybę dirbti andragoginị darbą (6 pav.). Gauti rezultatai atskleidžia ir patvirtina PKT sąsajas 
su suaugusiujų švietimu ir mokymu / mokymusi bei andragogo organizatoriaus profesionalumo svarbą, siekiant PKT kokybès.

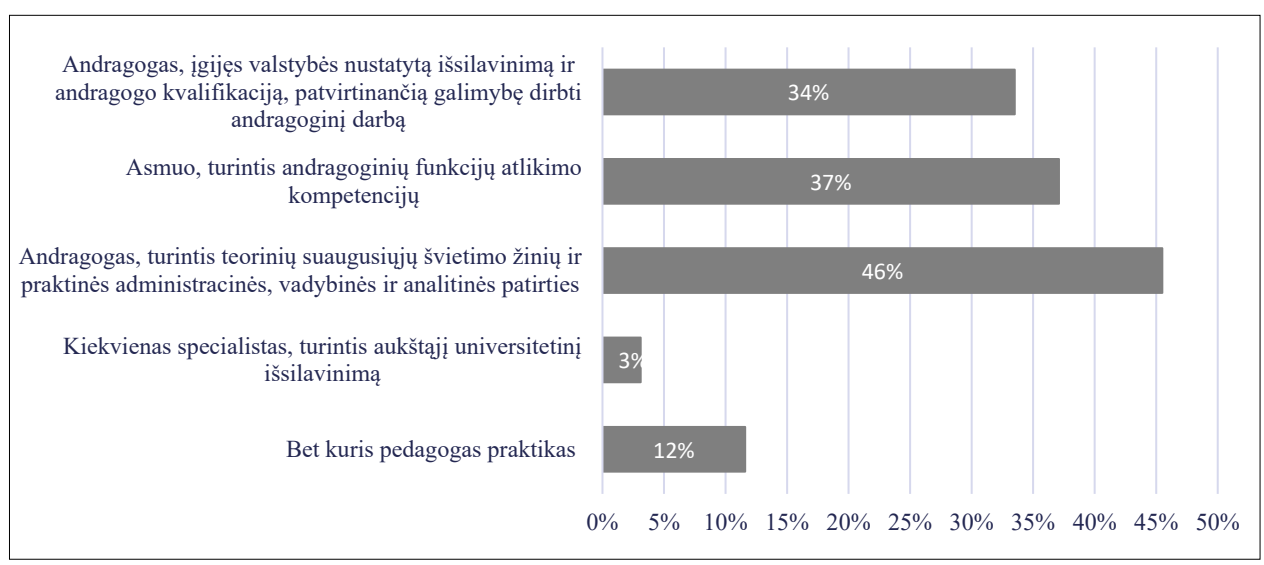

6 pav. Respondentų nuomonių, kas gali atlikti andragogo, teikiančio PKT paslaugas, funkcijas, pasiskirstymas

Siekta išsiaiškinti, kaip respondentai vertina andragogo organizatoriaus gebėjimų svarbą jo profesinès veiklos sričių bei atliekamų funkcijų aspektu. Remiantis empiriniais duomenimis, svarbiausiu laikomas andragogo organizatoriaus gebejjimas „bendradarbiauti su švietimo ir kitu sektorių institucijomis“, ịvertintas 4,39 balo, tai rodo gana aukštą jo svarbumo laipsnị. Mažiausiai svarbiu laikomas gebejjimas „valdyti finansus, organizuoti viešuosius pirkimus“, įvertintas 3,52 balo, kuris yra vidutiniškai svarbus, lyginant su žemiausiu galimu įvertinimu „1“.

Tyrimu nustatyta, kad šiek tiek daugiau nei pusė apklaustujų (53 proc.) mano, kad pagrindinis andragogo organizatoriaus vaidmuo yra kvalifikacijos tobulinimo renginiu planavimas, organizavimas, igyvendinimas ir vertinimas. Kita pusé (50 proc.) teigia, kad svarbiausia gebėti pedagogams organizuoti kokybiškus, efektyvius ir rezultatyvius mokymus. Mažesnè dalis respondentų (35 proc.) mano, kad svarbi konsultacinè, technologinè, metodinè ir ekspertinè andragogo organizatoriaus pagalba mokytojui. Tarpininkavimą, kaip pagrindinį andragogo organizatoriaus vaidmeni, perduodant nacionalinio lygmens švietimo institucijų informaciją ugdymo ịstaigoms, pedagogams regionuose (pvz., ŠMM, UPC švietimo aktualijų, teisès aktų ir kitais klausimais) nurodė 21 proc. apklaustujų, o pedagogų mokymosi bendruomenès telkimą, naujų mokymosi formų diegimą - 19 proc. Remiantis gautais rezultatais, galima teigti, kad didžioji dalis respondentų andragogo organizatoriaus vaidmenį mato kokybiškų pedagogams skirtų mokymosi programų realizavimo srityje - nuo jų planavimo iki praktinio pritaikymo efektyvumo matavimo. 
Pusė pedagogų (50 proc.) teigia, kad andragogas organizatorius juos labiausiai motyvuoja tobulinti kvalifikaciją, igyti naujų kompetencijų ir puoselèti turimas iniciatyviai bendradarbiaudamas, šviesdamas apie ịvairias mokymosi galimybes, sukurdamas atviro visiems paslaugu teikejjo ịvaizdị. 45 proc. pedagogų nurode, kad jų motyvacija mokytis kyla, kai andragogas organizuoja ir moderuoja įvairius renginius, susitikimus, veda užsièmimus ir pan. Daugiau nei trečdaliui (34 proc.) apklaustujų svarbu, kad andragogas organizatorius pats būtų aktyvus mokymosi proceso dalyvis ( 7 pav.). PKT kontekste, remiantis apklaustujų nuomonėmis, išryškẻja andragogo organizatoriaus ne tik profesinių kompetencijų, bet ir asmeninių savybių svarba. Be to, pedagogų keliami reikalavimai arba lūkesčiai dèl andragogo organizatoriaus asmenybės ir profesinių kompetencijų atskleidžia dar netyrinètą tyrimo konstruktą - būtinybę jam pačiam nuolat tobulinti kvalifikaciją ir kompetencijas bei ịgyti naujų. Tai gali būti prielaida patvirtinti andragogo kvalifikacijos tobulinimo tvarką, formalizuoti igyjamas kompetencijas, taip žengiant dar vieną žingsni link andragogo profesijos pripažinimo tiek vidaus, tiek išorès profesionalizacijos aspektu.

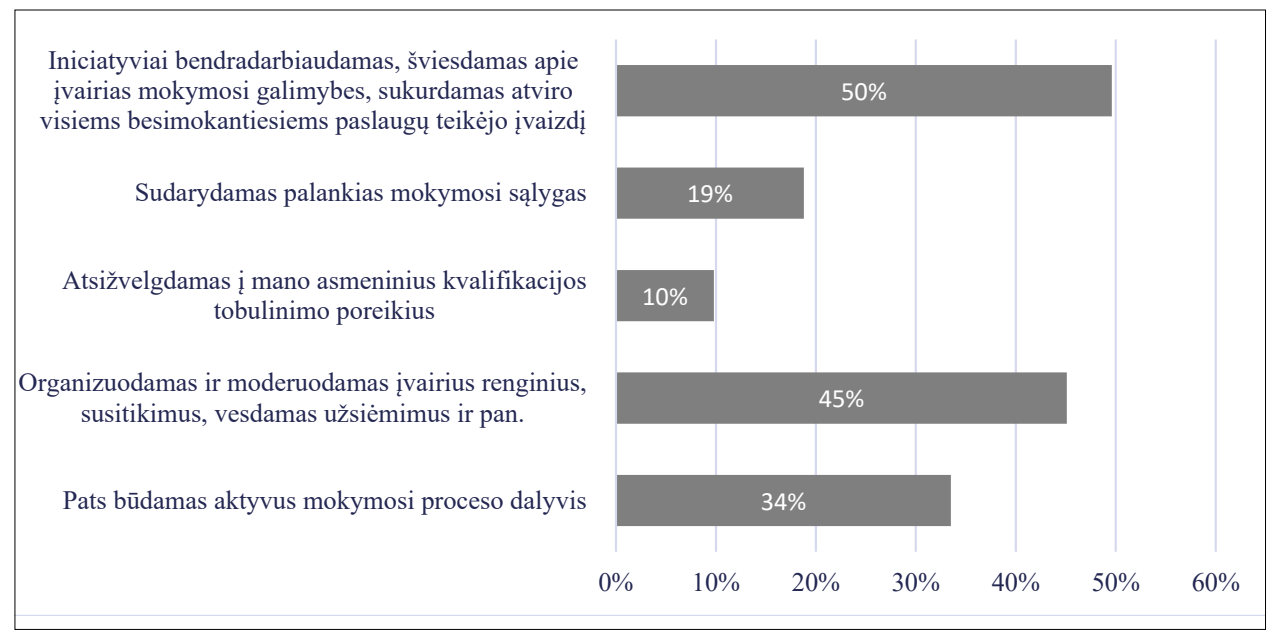

7 pav. Respondentų nuomonių, kaip andragogas organizatorius motyvuoja mokytis, pasiskirstymas

Tyrimu siekta nustatyti, ar respondentų nurodytų andragogo organizatoriaus atliekamų mokymosi paslaugų kokybės funkcijų pedagogams užtikrinimas ir jų motyvavimas yra susiję. Taikant chi kvadrato $\left(\chi^{2}\right)$ kriterijų, nustatytas statistiškai reikšmingas ryšys. Analizuojant respondentų požiūrị ị andragogo organizatoriaus kvalifikaciją ir kompetencijas, nustatytas statistiškai reikšmingas ryšys tarp to, kas, jų nuomone, gali atlikti andragogo, teikiančio PKT paslaugas, funkcijas, ir 
kokiomis priemonėmis andragogas organizatorius juos labiausiai motyvuoja mokytis. Remiantis nustatytais koreliaciniais ryšiais, galima teigti, kad tie pedagogai, kuriems svarbu, jog andragogas organizatorius turètu ne tik praktinès administracinès, vadybinès ir analitinès patirties, bet ir teorinių žinių, andragogo organizatoriaus vaidmenị labiau tapatina su atvira ir iniciatyviai bendradarbiaujančia PKT paslaugas teikiančia institucija. Tuo tarpu pedagogai, kuriems svarbiau, kad andragogas organizatorius turètų kompetencijų atlikti andragogo funkcijas, labiau pageidautų, kad jis pats aktyviai įsitrauktų ị mokymosi procesą. Be to, remiantis gautais duomenimis, galima daryti prielaidą, kad tie pedagogai, kuriems svarbus jų asmeninių mokymosi poreikių patenkinimas, palankios mokymosi aplinkos sukūrimas ir tai, kad andragogas organizatorius pats būtų aktyviu mokymosi proceso dalyviu, labiau pageidautų užmegzti asmeninị ryši su juo pačiu. O tie pedagogai, kurie nurodo mokymosi programų igyvendinimo kokybės ir kolektyvinių mokymosi poreikių tyrimų svarbą kokybės užtikrinimo aspektu, labiau linkę andragogą organizatorių traktuoti plačiau, t. y. kaip mokymosi paslaugas pedagogams teikiančią instituciją ar jos atstovą. Tuo tarpu pedagogai, teigiantys, kad vienas iš andragogo organizatoriaus vaidmenu yra tarpininkavimas tarp nacionalinio lygio švietimo institucijų perduodant nacionalinio lygmens švietimo institucijų informaciją ugdymo ịstaigoms, pedagogams regionuose, mano, jog jis turètų užtikrinti šalies bendros suaugusiujų švietimo politikos iggyvendinimą regionuose. Tai dar kartą įrodo, kad andragogo organizatoriaus funkcijas turi atlikti andragogas profesionalas, nes igyvendinant bendrą suaugusiujų švietimo politiką būtina ne tik perduoti informaciją, bet ir užtikrinti kokybès stebėseną.

Apskaičiuotas rangų vidurkis atskleidè, kad tyrime dalyvavę pedagogai geriausiai vertina Klaipedos rajono andragogų organizatorių kompetencijas ir profesionalumą teikiant PKT paslaugas $(4,34)$. Gerai, bet kiek mažiau įvertintos andragogu organizatoriu vadybinès $(4,31)$, bendravimo ir bendradarbiavimo $(4,28)$ kompetencijos. Nuomonių, ar respondentai Klaipėdos rajone patenkinti andragogų organizatorių teikiamomis PKT paslaugomis, vidurkis siekia 4,27. Ivertinę andragogų organizatoriu kompetencijas, toliau respondentai nurodè, kad domisi švietimo aktualijomis, todèl jiems svarbūs ne tik jų individualūs, bet ir bendri PKT tikslai $(4,22)$, o PKT renginių atitikimą švietimo aktualijoms vertina 4,24. Apklaustieji sutinka, kad andragogai, organizuojantys PKT Klaipėdos rajone, pakankamai dèmesio skiria kvalifikacijos tobulinimo renginių kokybei $(4,19)$. Pedagogų teigimu, naujas žinias jie pritaiko profesinejje veikloje $(4,16)$, igytos kompetencijos padeda jiems gerinti ne tik pedagoginę, bet ir andragoginę veiklą $(4,15)$. Gerai, tik kiek mažiau atsiliepimų pateikta apie andragogų organizatorių edukacinès veiklos srities kompetencijas, kurios apima mokymo/si programų pedagogams igyvendinimą. Taigi gautas toks respondentų nuomonių vidurkis vertinant: 1) lektorių 
Nomeda Skliuderienè, Gitana Tolutienè

kompetencijas $-4,14 ; 2$ ) pedagogams siūlomų kvalifikacijos tobulinimo programų naudingumą $-4,08 ; 3$ ) taikomų mokymosi formų, būdų, metodų ịvairumą - 4,06. Pedagogų nuomone, jiems pakanka informacijos apie andragogų organizatoriu Klaipedos rajone vykdomą veiklą $(4,05)$, pedagogams organizuojami renginiai atitinka jų individualius kvalifikacijos tobulinimo poreikius $(4,04)$, o jų profesinė veikla po kiekvieno tokio renginio tobuleja $(3,96)$. Pedagogai sutinka, kad yra tiriamas grịžtamasis ryšys apie ịvykusių kvalifikacijos tobulinimo renginių kokybę $(3,90)$. Apskaičiavus ranginị vidurkị teiginio, ar respondentai yra patenkinti andragogų organizatorių Klaipėdos rajone teikiamomis PKT paslaugomis, nustatyta, kad labiausiai patenkinti yra menų ir technologijų dalykų atstovai $(4,78)$ bei ikimokyklinio ir priešmokyklinio ugdymo pedagogai $(4,75)$, mažiausiai patenkinti socialinių mokslų $(3,94)$, gimtosios kalbos ir literatūros mokytojai $(3,96)$.

Galima teigti, kad viena iš PKT silpnybių - grižtamojo ryšio dèl praktinio PKT pritaikomumo nebuvimas. Mokslininkai, atlikę Lietuvos PKT sistemos analizę (2011), išskyrè vieną iš sẻkmingo PKT funkcionavimo sąlygų - PKT proceso organizavimas turi būti susietas su ị rezultatą (kokybišką veiklą) orientuotu valdymu. Remiantis šia rekomendacija, respondentų klausta, ar jie sutiktų informuoti andragogą organizatorių, kaip pasikeitè pedagoginès veiklos kokybė jiems patobulinus kompetencijas pagal konkrečią mokymo programą. Didžioji dauguma (71 proc.) nurodè, kad sutiktų. Be to, jų klausta, kaip būtų naudinga tai padaryti. 43 proc. pedagogų nurodè, kad naudingiausia būtų dalyko mokytojų metodinio būrelio ataskaitiniame mokslo metų pasitarime atlikti refleksiją, kurie kvalifikacijos tobulinimo renginiai, mokymo programos pedagogams buvo naudingos, kaip konkrečiai pasitarnavo jų profesinès veiklos kokybei ir pan.: 21 proc. pedagogu apsiribotų atsiliepimu renginio ar programos vertinimo anketoje; 16 proc. respondentų nuomone, užtektų pasikliauti kvalifikacijos tobulinimo renginyje dalyvavusių pedagogų žodiniu atsakymu; 12 proc. nurodè, kad naudinga būtų apklausti mokinius, kaip patobulèjo pamoka, ugdymo procesas mokytojui grị̌us iš kvalifikacijos tobulinimo renginio. Remiantis gautais duomenimis, galima teigti, kad dauguma apklaustų pedagogų suvokia jų pačių aktyvaus dalyvavimo svarbą ne tik suaugusiujų švietimo ir mokymo / mokymosi procesuose, bet ir užtikrinant PKT proceso stebėseną bei kokybę. Kadangi andragogas organizatorius, planuodamas PKT, atsižvelgia ị jų poreikius ir lūkesčius, vertinant PKT, pedagogų ir andragogų organizatorių bendradarbiavimas bus naudingesnis nustatant PKT stiprybes ir silpnybes, tuo remiantis bus planuojamas kokybiškesnis PKT procesas.

Apibendrinant pagrindinių empirinių rezultatų analizę, galima teigti, kad dauguma tyrime dalyvavusių pedagogų, suvokdami PKT sąsajas su suaugusiụjų švietimu ir mokymu / mokymusi, akcentuoja PKT galimybes gerinant ne tik pedagoginę, bet ir andragoginę veiklą, igyjant naujų kompetencijų, be abejo, įžvelgia šio 
proceso sudètingumą, pradedant profesinès veiklos įsivertinimu, baigiant nauju kompetencijų praktiniu pritaikymu, ir, planuodami kvalifikacijos tobulinimą, vadovaujasi tiek asmeniniais, tiek ugdymo ịstaigos poreikiais, o tai pagrindžia PKT koncepcijos subsidiarumo principą. Andragogas organizatorius turètu atsižvelgti i pedagogų požiūrị, kad mokymuose svarbiausia yra praktinė nauda, ir laikytis geriausios ugdymo praktikos principo, didžiają dalį kvalifikacijos tobulinimo veiklų numatydamas autentiškoje pedagoginès veiklos aplinkoje arba sudarydamas sąlygas jiems patiems išbandyti naują medžiagą bei metodus. Respondentų nuomonės analizė atskleidè, kad andragogas organizatorius pedagogams teikiamų mokymosi paslaugų kokybę efektyviausiai užtikrina veikdamas visose profesinès veiklos srityse: edukacinèje, vadybinèje, tiriamojoje. Atsižvelgiant ị apklaustų pedagogų lūkesčius, pagrindinė andragogo organizatoriaus funkcijų paskirtis - kokybiškų mokymosi programų pedagogams ịgvendinimas: nuo jų suplanavimo iki praktinio pritaikymo efektyvumo matavimo. Viena vertus, pedagogų keliami reikalavimai ir lūkesčiai andragogo organizatoriaus asmenybei ir profesinèms kompetencijoms turètų byloti būtinybę jam pačiam nuolat tobulinti kvalifikaciją - turèti kompleksą pedagogus ịkvepiančių kompetencijų; kita vertus, pedagogų pageidavimas matyti andragogą organizatorių aktyviu mokymosi proceso dalyviu iškelia jam kitą sąlygą: vertinant situaciją visada būti pasirengusiam tapti lygiaverčiu jų partneriu mokymosi motyvavimo tikslais. Tyrimas atskleide, kad pedagogai yra patenkinti Klaipedos rajone teikiamomis PKT paslaugomis ir tiek andragogų organizatorių kompetencijas, tiek veiklas ir funkcijas, susijusias su PKT proceso organizavimu, vertina gerai. Jų nuomone, andragogai organizatoriai dažniau patys turètų tapti mokymosi proceso dalyviais, moderuoti ịvairius užsièmimus ir kurti atviro visiems pedagogams, norintiems tobulinti kvalifikaciją bei iggyti naujų kompetencijų, kokybiškų paslaugų teikèjo įvaizdị.

\section{Išvados ir rekomendacijos}

Kvalifikacijos tobulinimas pirmiausia susijęs su suaugusiujų švietimu ir mokymu / mokymusi. PKT aktualus ne tik kaip mokytojo pedagoginès, bet ir kaip andragoginès veiklos gerinimo, naujų kompetencijų igijimo šaltinis. Šioje srityje andragogo profesinès veiklos spektras labai platus, todèl jo atliekamus vaidmenis turètų pasidalyti grupė andragogų profesionalų: vadybininkas, organizatorius, analitikas ir kt. Tačiau profesinèje realybejje dažnai tas pats andragogas organizatorius turi disponuoti visomis andragogo profesinès veiklos kompetencijomis ir veikti rezultatyviai atsižvelgdamas ne tik ị profesinès veiklos situaciją, bet ir ị kontekstą. PKT paslaugų kokybė priklauso nuo andragogo organizatoriaus profesionalumo. Tokie aukšti jam keliami reikalavimai pabrèžia tiek vidaus, tiek išorès andragogo organizatoriaus profesionalizacijos svarbą. 
Empirinių duomenų analizė atskleidẻ pedagogų požiūrio ị andragogo organizatoriaus veiklą, funkcijas ir kompetencijas skirtumus ịvairiais aspektais. Mokymosi paslaugų kokybės pedagogams užtikrinimo aspektu andragogui organizatoriui svarbu profesionaliai veikti vadybinèje, tyriminèje ir edukacinejje veiklos srityse, užtikrinant kokybišką mokymosi programų iggyvendinimą, pradedant jų planavimu ir baigiant praktinio pritaikymo efektyvumo matavimu. Pedagogų motyvavimo mokytis aspektu andragogas organizatorius dažnai turètų pats tapti mokymosi proceso dalyviu, užsièmimų moderatoriumi ir kurti atviro visiems besimokantiesiems kokybiškų paslaugų teikèjo ịvaizdị, o paramos / pagalbos teikimo kvalifikaciją tobulinantiems pedagogams aspektas iškelia andragogui organizatoriui sąlygą ịvaldyti konsultavimo veiklos sritị ir jai būtinas kompetencijas. Toks andragogo organizatoriaus profesinès veiklos ịvairialypiškumas ir daugiafunkcionalumas byloja būtinybę būti savo srities profesionalu teikiant kokybiškas PKT paslaugas.

Tyrimas patvirtino, kad PKT efektyvumas priklauso nuo andragogo organizatoriaus profesionalumo. Andragogui organizatoriui svarbu ne tik užtikrinti kokybišką PKT procesą, bet ir plètoti sèkmingą bendradarbiavimą su kitomis švietimo bei ugdymo institucijomis, siekiant, kad pedagogai tikslingai planuotu ir sistemingai igyvendintų kvalifikacijos tobulinimą, atsižvelgdami ị projektuojamą profesinès veiklos gerinimą, naujų kompetencijų igijimą. Toks platus kryptingos veiklos PKT srityje spektras skatina andragogą organizatorių tobulèti savo profesinejje srityje.

Remiantis tyrimo rezultatų analize ir išvadomis, pateikiamos šios rekomendacijos andragogams, organizuojantiems PKT Klaipedos rajone:

1. Igyvendinant PKT programas, numatyti tokias pedagogų mokymosi formas, būdus, metodus, kurie būtų praktiškai naudingi, kad kvalifikaciją tobulinantys ir naujų kompetencijų igyjantys pedagogai galètų perimti geriausias ugdymo praktikas.

2. Siekiant suaugusiųų mokymosi paslaugų kokybès, ištirti pedagogų individualius ir kolektyvinius mokymosi poreikius, parengti veiksmingas mokymo programų igyvendinimo strategijas ir metodus, užtikrinti mokymų programos bei praktinio pritaikomumo ryší.

3. Profesionalumo aspektu andragogams organizatoriams siekti teorinių suaugusiųju švietimo žinių ir praktinès administracinès, vadybinès, konsultacinès bei analitinès patirties dermès, daugiau dèmesio skiriant konsultavimo veiklos srities kompetencijų igijimui.

4. Motyvavimo aspektu andragogams organizatoriams iniciatyviai bendrauti ir bendradarbiauti su pedagogais individualiai, dažniau patiems tapti mokymosi proceso dalyviais ar kvalifikacijos tobulinimo renginių moderatoriais, tai paskatintų pedagogus labiau ịsitraukti ị kvalifikacijos tobulinimo ir naujų kompetencijų igijimo procesą. 


\section{Literatūra}

Adomaitienė, J., Zubrickienė, I. (2016). Projektai mokymosi procese: andragoginès squveikos optimizavimo aspektas. Monografija. Klaipėda: KU leidykla.

Andragogo profesinès veiklos aprašas. (2013). [Interaktyvus]. Prieiga internete: http://www.smm.lt/web/lt/ teisesaktai/tei/ministro-isakymai [žiūrèta 2018-04-10].

Andriekienè, R. M. (2011). Andragogų profesionalizacija atliekamų vaidmenų aspektu. Andragogika, Nr. 2, p. 13-29. Klaipėda: KU leidykla.

Andriekienė, R. M., Anužienė, B. (2006). Andragoginiai kompetenciju tobulinimo aspektai tęstiniame profesiniame mokyme. Monografija. Klaipèda: KU leidykla.

Andriekienė, R. M., Jatkauskienė, B., Jatkauskas, E. (2009). Andragogo veiklos ypatumai slaugos specialistų kvalifikacijos tobulinimo aspektu. Sveikatos mokslai, Nr. 2, T. 19. Vilnius.

Jatkauskienè, B. (2013). Andragogu profesionalizacijos sistemos profesionali raiška. Monografija. Klaipėda: KU leidykla.

Juozaitis, A. M. (2008). Suaugusiuju mokytoju profesionalizacija tobulinant andragoginę veiklą. Monografija. Kaunas: VDU leidykla.

Knowles, M., Holton, E., Swanson, R. (2008). The adult learner: the definitive classic in adult education and human resource development. Houston: TX: Gulf Publishing.

LR Neformaliojo suaugusiujų švietimo ir tęstinio mokymosi įstatymas. (2014). [Interaktyvus]. Prieiga internete: http://www3.lrs.lt/pls/inter3/dokpaieska.showdoc_1?p_id=478674 [žiūrèta 2018-04-03].

Lietuvos Respublikos švietimo ịstatymas. (2011). [Interaktyvus]. Prieiga internete: http://www3.lrs.lt/pls/inter2/ dokpaieska.showdoc_1?p_id=458774 [žiūrèta 2018-04-02].

LR švietimo ir mokslo ministro ịsakymas Nr. V-774 „Dèl reikalavimu mokytojų kvalifikacijai aprašo patvirtinimo “. (2014). [Interaktyvus]. Prieiga internete: https://www.e-tar.1t/portal/1t/legalAct/85dc8a705b4d11e487eff7b42 4bd0f08 [žiūrèta 2018-04-02].

Mokymosi visa gyvenima užtikrinimo strategija. (2008). [Interaktyvus]. Prieiga internete: https://www.e-tar.lt/ acc/legalAct.html?documentId=TAR.BCAEABD601EC [žiūrèta 2018-04-02].

Pedagogu kvalifikacijos tobulinimo koncepcija. (2012). [Interaktyvus]. Prieiga internete: http://www.upc.smm.lt/ naujienos/pkt/koncepcija.php [žiūrèta 2018-04-10].

Pedagogu kvalifikacijos tobulinimo sistemos analize. (2011). [Interaktyvus]. Prieiga internete: http://www.upc. smm.lt/projektai/perkva/naujienos/PKT_analize_120105.pdf [žiūrèta 2018-04-02].

Švietimo valdymo informacine sistema. (2016). [Interaktyvus]. Prieiga internete: <http://svis.emokykla.lt/lt/ index/a_view/47 [žiūrèta 2018-09-02].

Teresevičienè, M., Gedvilienè, G., Zuevičiūtė, V. (2006). Andragogika. Kaunas: VDU leidykla.

Valstybiné švietimo 2013-2022 metu strategija. (2013). [Interaktyvi]. Prieiga internete: https://www.etar.lt/portal/ legalAct.html?documentId=b1 fb6cc089d911e397b5c02d3197f382 [žiūrèta 2018-04-15].

Zuzevičiūtė, V., Teresevičiené, M. (2008). Suaugusiuju mokymasis. Andragoginès veiklos perspektyva ir andragoginès veiklos modelis. Kaunas: VDU leidykla.

\section{EDUCATORS' QUALIFICATION TRAINING EFFICIENCY FROM THE ASPECT OF THE COORDINATING ANDRAGOGUE'S PRACTICE}

\section{Nomeda Skliuderienė, Gitana Tolutienè}

\section{Summary}

Modern knowledge society and educational system's processes of change raise new requirements for teachers' qualification and encourage them to improve. 
LR Law on Education (2011) article 2 (20) stipulates that teachers' qualification in accordance with the procedures laid down in LR legal acts is recognised as a whole of a person's possessed competences or professional experience and possessed competences necessary for student education. Since to complete a job that is regulated by law a certain qualification (or competence) is needed, from the 2 paragraph it follows that in seeking higher quality of education and training, qualification development is one of the first necessary conditions to achieve it. However, the question is, whether the teacher can deal with these processes by developing his pedagogical activities, or does he need competent assistance, in particular assistance of the andragogue?

After the analysis of interaction between the teacher and the andragogue, and the spheres of andragogue's activities, it appears that the andragogue organiser is the one who helps the teacher to self-assess his activity, identify successes of pedagogical activities and areas for improvement and foresee the direction of qualification development. In Lithuania these functions are performed by schools' deputy principals, specialists of education departments monitoring and assessing teachers' activities, specialists of teachers' education centre closely cooperating with educational institutions. However, in the aspect of ensuring the quality of teachers' qualification development andragogue organiser plays the main role in the teachers' qualification development process while acting in the professional spheres of education, management and research activity.

LR Law on Education 2011, State's Education Strategies 2013-2022, Conception of Teachers' Qualification Development 2012, Description of Requirements for Teachers' Qualification 2014 and other documents regulating teachers' qualification development determine requirements raised for teachers and teachers' qualification development opportunities. However, it seems that teachers' qualification development is frequently characterised as fragmentary, it lacks research on the needs of teachers' qualification development, planning, connection with the education process and practical application that justifies the relevance of this article. On the other hand, in recent years there are many objections to requirements raised to providers of teachers' qualification development services and to the assurance of quality of these services in Lithuania's Educational institutions.

The number of documents regulating professional activity of andragogues taking part in teachers' qualification development process is low, contrary to the number of documents regulating teachers' professional activity: Description of Andragogues Professional Activity 2013, LR Non-formal Adult Education Act 2014, Strategy of Lifelong Learning Assurance 2008, State's Education Strategies 2013-2022, provisions of 2013 and other. With the growing recognition of importance of the andragogue professional various document drafts are prepared. Many 
researchers (Adomaitienè et. al., 2016; Jatkauskienė, 2013; Andriekienè, 2011; Zuzevičiūtè et. al., 2008; Juozaitis, 2008; Andriekiené et. al., 2006, 2009; Knowles et. al., 2007; Teresevičienė et. al., 2006, and others) who analysed the andragogue's activity spheres, functions, competences and roles that they play, have determined their diversity. Today, as regards teachers' qualification development, training, teaching and the lecturer's role is not as stressed as the technologies of andragogy and andragogical activity, support, helping the adult learner, management, reflection, other activity spheres and the roles played by andragogues analysts (researchers), organisers, consultants, counselors, managers, mentors.

Observing the tendencies of the education system politics and the analysis of educators' qualification training problems, it becomes clear, that the importance of the coordinating andragogue's role in the area of educators' qualification training, and his professionalism are underestimated. Analytical, managerial, and other general and professional competences are necessary. The "fragmentary" organisation of educators' qualification training is acknowledged as problematic and having no positive influence on the students' education process. Even though the roles, practice spheres, functions, and the required competencies of the andragogue are described by scientists from Lithuania and abroad, and the Lithuanian educators' qualification training is constantly a subject of discussion, this area, influenced by constant analysis, raises a scientific problem: what is the role of the coordinating andragogue's professionalism, in pursuance of the educators' qualification training efficiency?

Object: the role of the coordinating andragogue in the educators' qualification training efficiency in Klaipeda district.

Aim: to reveal and substantiate the role of the coordinating andragogue's professionalism in the educators' qualification training efficiency.

Methods. Analysis of scientific literature and documents, in order to emphasize the positive and negative aspects of the coherence between the educators' qualification training and the coordinating andragogue's practice. Questionnaire of Klaipeda district educational institutions' pedagogues, in order to examine their attitude towards the practice and functions of the coordinating andragogue, in charge of the educators' qualification training process.

The main conclusions of the "educators' qualification training efficiency from the aspect of the coordinating andragogue's practice" survey:

The andragogue, who is involved in educators' qualification training, has a wide range of activities. Those activities should be performed by a group of professionals: a manager, a coordinator, an analyst, etc. However, in the professional reality, the same andragogue has to possess educational, managerial, and analytical competences, and to organise his work according to both - the professional 
situation and the context. The educators' qualification training quality depends on the coordinating andragogue's professionalism. Such high requirements emphasise both - the inner and outer - importance of the coordinating andragogue's professionalization.

The analysis of empirical documents revealed different aspects of educators' approaches towards the work of the coordinating andragogue. From the aspect of educational service quality, it is important for the coordinating andragogue to act professional in the managerial, analytical and educational areas, ensuring qualitative realization of educational programs, beginning with their planning and ending with the measurement of their practical application efficiency. In order to motivate learners, the coordinating andragogue should quite frequently become a participant of the educational process, moderate lectures, and create an open and approachable to all learners service provider's image. The aspect of providing assistance raises a term for the coordinating andragogue to master the area of consulting. Such a versatility and multifunctionality of the coordinating andragogue's practice emphasizes the necessity of being a professional in the field of educators' qualification training services.

The survey confirmed that the educators' qualification training efficiency depends on the professionalism of the coordinating andragogue. The coordinating andragogue not only has to ensure an efficient educators' qualification training process, but also develop a successful cooperation with other educational institutions, so that pedagogues could plan and accomplish their qualification training, given the planned students' learning results and progress. Such a wide range of targeted activities, without a doubt, requires professionalism of the coordinating andragogue.

On the ground of conducted research analysis and conclusions, here are the recommendations made for andragogues organising teachers' qualification development in Klaipeda district:

In the implementation of teachers' qualification development programmes provide for forms of learning that have practical benefits, so that teachers who are developing their qualification could adopt the best training practices;

In seeking quality of learning services, study teachers' individual and collective learning needs, provide for effective strategies and methods for implementation of learning programmes, ensure connection between the learning programme and practical application;

In the aspect of professionalism seek coherence of theoretical knowledge on adult education and practical administrative, management, consultative and analytical experience while focusing on acquiring competences in the sphere of consulting activity. 
In the aspect of motivating proactively communicate and cooperate with teachers individually, become learning process' participants or moderators of qualification development events more frequently. This would encourage teachers to become more involved in the qualification development process.

\footnotetext{
Nomeda Skliuderienè - magistrè (socialiniai mokslai - edukologija - 07S), metodininkè, Klaipėdos rajono švietimo centras.

Moksliniai interesai: andragogo profesionalizacija, andragogo vaidmenys, veiklos sritys ir funkcijos, andragogo profesionalumo vaidmuo pedagogų kvalifikacijos tobulinimo srityje.

Adresas: Kvietinių g. 30, LT-96112 Gargždai.

Tel. +37046453067 .

El. paštas: nomeda.skliuderiene@gmail.com
}

Nomeda Skliuderienè - master of Social Sciences (Education - 07S), methodologist, Educational Centre of Klaipeda District.

Scientific interests: andragogue professionalization; roles, activity areas and functions of andragogue; the role of andragogue's professionalizm in teachers in-service training and professional development.

Address: Kvietinių Str. 30, LT-96112 Gargždai.

Phone: +37046453067.

Gitana Tolutienė - docentè, daktarè (socialiniai mokslai - edukologija - 07S). Klaipėdos universiteto Socialinių ir humanitarinių mokslų fakulteto Tęstinių studijų instituto Andragogikos katedra.

Moksliniai interesai: suaugusiujų švietimo veikėjų profesionalizacijos procesas, andragogų, aukštosios mokyklos dėstytojų profesionalumo tobulinimas, andragogo edukacinè ir pagalbos veiklos sritys, suaugusių besimokančiųjų heterogeniškumo valdymas.

Adresas: Vilhelmo Berbomo g. 10-118, LT-92294 Klaipėda.

Tel. +37046398582 .

El. paštas: gitana.tolutiene@gmail.com

Gitana Tolutienè - associate professor, doctor of Social Sciences (Education - 07S). Klaipėda University Continuous Study Institute, Faculty of Social and Humanities Sciences, Department of Andragogy.

Scientific interests: the process of adult players professionalization; professional development of andragogues, high school teachers; andragogue's realization (educational) and assistance activities, the management of adult learners heterogeneity.

Address: Vilhelmo Berbomo Str. 10-118, LT-92294 Klaipèda.

Phone: +37046398582.

E-mail: gitana.tolutiene@gmail.com 